\title{
DESCOLA, Philippe. 2019. Une Écologie des Relations. Les grandes voix de la recherche. Paris: CNRS Editions/De vive voix, 53p.
}

Denise Machado Cardoso ${ }^{a}$

O livro Une Écologie des Relations é uma obra na qual Philippe Descola apresenta uma trajetória de pesquisa, ao mesmo tempo em que apresenta sua perspectiva para estudos acerca das continuidades e descontinuidades entre coletivos de seres humanos e não humanos, tendo como referência quatro formas de classificação, também por ele denominadas como ontologias: o animismo, o naturalismo, o totemismo e o analogismo.

Ao longo dos cinco capítulos que compõem o livro apresenta sua teorização do que ele denomina como Ecologia das Relações. Em breve introdução, apresenta sua formação como antropólogo, assinalando sua iniciação em Filosofia. A partir de suas leituras sobre etnologia percebeu que questões filosóficas universais poderiam ser temas de estudos e debates para além do continente europeu. Com influência direta de Maurice Godelier, decidiu-se efetivamente pela Antropologia. A experiência etnográfica foi impulsionada por Claude Lévi-Strauss

a Professora no Programa de Pós-Graduação em Sociologia e Antropologia (UFPA). Email: denisecardosoufpa@gmail.com. 
e a partir daí explica como se desenvolveu o interesse em pesquisar populações do continente americano.

No segundo capítulo descreve sua experiência entre os Achuar, povo que se localiza na região limite entre Equador e Peru, cuja população fala vários dialetos e mantém uma unidade cultural por outros aspectos. Além das considerações sobre os escassos estudos sobre esse povo, descreve-os em suas principais características belicosas como forma de proteção de seu território desde o início do avanço de exploradores e colonizadores.

Nos primeiros tempos em campo houve a presença da antropóloga Anne-Christine Taylor, sua companheira. Nesse início dedicaramse à aprendizagem da língua, além de estudos sobre formas de interação com o meio ambiente. Dentre as várias descobertas sobre plantas e animais, houve a constatação de que em boa parte do tempo esse povo canta para encantarias mágicas. Estes seres encantados denominados como Anent (que vem de Enentai, o coração) trazem discursos do coração, da alma e cantam mentalmente ou murmuram, pois, suas palavras são difíceis de serem compreendidas. A interpretação de sonhos também é uma maneira de se comunicar com seres encantados. Com auxílio de especialistas, interpretar sonhos da noite anterior faz com que um mundo intermediário se apresente e oportunize a troca de mensagens entre seres humanos e não humanos.

O estudo sobre a adaptação dos Achuar a dois ecossistemas principais indicam: um meio inter fluvial, com colinas e solos pobres, uma floresta densa, uma população de animais predominantemente arborícola; e um vale de grande rio com área de pastagem. Descola mostra três grandes 'porosidades' entre o mundo dos jardins: a horticultura sobre solo queimado, o mundo da coleta e o mundo da caça. Não há grandes distâncias espaciais entre florestas e jardins de tal modo que os pequenos animais da floresta transitam nos jardins.

No capítulo 'Totemismo, animismo, naturalismo e analogismo' o autor relata suas reflexões ao retornar para a França e conclusão de sua tese, sob orientação de Claude Lévi-Strauss. Intitulada 'A natureza 
doméstica' ele explica que humanos no espaço doméstico estão divididos em duas categorias: pela consanguinidade e pela afinidade. A partir daí indica que entre vários povos ameríndios da Amazônia, inclusive os Achuar, essa forma de categorizar não se restringe às relações sociais entre humanos, mas, também, entre humanos e não humanos.

O totemismo enquanto uma projeção análoga, com descontinuidade natural e social, e com diferenças morfológicas, é um modelo que não pode ser operacionalizado do mesmo modo entre os povos ameríndios, sejam eles da América do Norte ou da Amazônia. Ao invés de observar aspectos naturais para pensar as categorias sociais, utilizou as categorias sociais de afinidade e consanguinidade para pensar as relações com objetos naturais. Concluiu que não há distinções universais entre natureza e cultura.

De acordo com a lógica presente no totemismo os grupos mistos de humanos e não humanos são constituídos de seres morfologicamente distintos, mas que partilham qualidades psíquicas e morais. Tais qualidades psíquicas são definidas de maneira abstrata. Algumas das qualidades são compartilhadas por humanos e não humanos, independente de suas formas, e são representadas por um ser totêmico.

Ao relacionar o animismo e o naturalismo acrescenta uma terceira forma de percepção das continuidades e descontinuidades entre humanos e não humanos, visto que há um conjunto de qualidades psíquicas e morais partilhadas por todos que definem o grupo totêmico, e elas diferem um grupo do outro.

Há, ainda, sociedades que não apresentam as características do animismo, nem do naturalismo ou do totemismo. Essas sociedades se utilizam da classificação pelo analogismo. Estas classificações formam uma maneira sistemática para estabelecer a ordem nas sociedades e elas são familiares visto que são anteriores ao naturalismo. E os povos europeus eram analogistas, notadamente no Renascimento bem como na Idade Média e na Antiguidade. Atualmente, o analogismo se expandiu no Extremo Oriente, nas populações ameríndias dos Andes e do México, e grande parte da África. 
O modo de identificação analógica requer elementos estruturantes que podem conter singularidades e disparidades. Um exemplo europeu para elucidar essa forma de classificação analógica é o sistema social no qual há Deus como o mais perfeito numa corrente cujo oposto está o ser insignificante. Assim, o analogismo permite que se reagrupe uma totalidade de elementos que se mantém pelas diferenças, inclusive pelas menores diferenças.

No capítulo que encerra o livro, Descola reitera suas considerações sobre os quatro modelos de ontologias por ele sistematizados (animismo, naturalismo, totemismo e analogismo). As suas elaborações partem de discursos diretos de suas pesquisas e de experiências etnográficas realizadas por outras pessoas, somando-se a obras de diferentes áreas de investigação.

Ressalta que as formas pelas quais o fazer e o objeto antropológico vem se configurando com a imagem, isto é, com os signos a partir de suas significações se traduzem no retrato da realidade social, logo, a figuração não necessariamente é objetificado, a expressão humana como o corpo, são exemplos concretos de imagem. $\mathrm{O}$ autor leva a uma ampliação dos modos de percepções, mostrando as rupturas de velhos conceitos.

Uma outra possibilidade de pesquisas futuras está relacionada também aos Achuar e outros povos com saberes ancestrais e, portanto, tradicionais, trata-se da questão das espécies. Nesse contexto Achuar, cada espécie não humana é dotada de uma alma que constitui um coletivo com o qual os humanos interagem. Essa lógica se expressa a partir de regras sociais utilizadas para reger as relações tanto entre humanos entre si quanto destes com os não humanos.

A visão que os povos europeus têm de outras regiões do mundo nem sempre é a mais adequada para explicar as realidades de povos de outros continentes. Portanto, às conceitualizações instituídas a partir do conhecimento científico produzido na Europa serão somadas outras produzidas segundo a lógica do conhecimento de povos que habitam os vários continentes. 
Nos anos que estão porvir há uma proposta de demonstrar essa diversidade de percepções acerca dos prolongamentos do meio ambiente, dos modos de vida, e como as coletividades englobam humanos e não humanos no que se refere à apropriação de seus territórios como lugar de pertencimento, não mais como espaços concretos, mas como as representações simbólicas pelas quais se situam. A indicação de pesquisas futuras cabe tanto ao próprio Philippe Descola quanto instiga outras pessoas interessadas no tema a desenvolver pesquisas segundo esse viés que introduz novas percepções.

Recebido em abril 2020. Aprovado em julho 2020. 